\title{
The Limits of Perception in the Tonal Orthographies of three-tone Systems
}

\author{
Kolawole Adeniyi (Ile-Ife)
}

\begin{abstract}
This article discusses the representation of downstep in the tonal orthographies of some threetone languages of West Benue-Congo, in the light of the phonological properties of tone in the languages. Ebira has total downstep, which makes both downstepped high and downstepped mid to be perceived at a level close to outright low tone, and written so; downstepped high in Igala is realised around the level of the mid tone and is often written as mid in the orthography. In Gwari, the docking of floating high tonal morpheme and contour simplification interact with downstep in such a way that downstepped high tones are frequently written as mid. It is shown that these situations arise because surface tone perception is taken as the sole parameter for tone categorisation, ignoring the underlying tones of lexical items in the languages as well as the number of tones and possible terracing-triggered intersections between the tones. It is argued that the orthographies of the languages will be far more accurate if these obvious facts of downstep are incorporated.
\end{abstract}

\section{$1 \quad$ Introduction}

It is not uncommon to find languages whose orthographies are inaccurate or at variance with the language facts (cf. Elugbe 1991: 49). In Nupe, Okpe and Urhobo, three well-documented examples within West Benue-Congo (WBC), the inaccuracies are linked to diachronic changes in the vowel systems (cf. Hyman 1970; Elugbe 1991).Also, [1] and [n] are in complementary distribution in Urhobo and Yoruba (cf. Bamgbose 1990: 13; Elugbe 1991; Akinlabi 2004: 458), but in both languages, the two sounds are given independent orthographic symbols, a reality amounting to "over-differentiation". In the case of tone, the first problem is usually that of non-representation. This is partly because of the so-called trouble of adding diacritic marks to symbols of sounds and partly because of the erroneous believe that tones are secondary and their contributions to larger linguistic units can be inferred from the segmental constituents of such units (Bamgbose 1965: 15; Lojenga 2011: 1; Williamson 1980, 1984: 41). Another problem with tone, which is the focus of this article, relates to tones that are non-automatically lowered in environments containing no phonetic low tones. This is referred to as downstep in the literature and the facts of such lowering are usually not included in orthographical designs. In many instances, such orthographical discrepancies owe to perception. 
Hume and Johnson (2001) note that perception is capable of influencing phonology in at least three ways: "failure to perceptually compensate for articulatory effects, avoidance of weakly perceptible contrasts, and avoidance of noticeable alternations." In the first case, listeners may misinterpret certain articulatory gestures, thereby perceiving such as different sounds. In the second, listeners may simply miss or ignore contrasts that are not clearly distinct, while in the third instance listeners may discard contrasts if that enhances communication. It is the second reason that relates most to our discussion of tone categorisation in this article, that is, listeners and especially orthography designers missed certain tonal contrasts because such are not distinct enough when a tone is lowered to a level close to a separate lower tone. It should be noted that $\mathrm{L}$ is marked with a superscript grave accent ( ' ) on the vowel or syllabic consonant, M is marked with a superscript macron $\left({ }^{-}\right)$, and $\mathrm{H}$ with a superscript acute accent $\left(^{\prime}\right)$ on the vowel or syllabic consonant. ${ }^{1}$

It needs to be reiterated that this article examines the tonological system of Ebira, Gwari and Igala and the connection it has with the tonal aspect of the orthographies of the languages. Essentially, orthographies are to derive from the phonologies of languages; hence an orthography is only as accurate as the phonological analysis on which it is based. In case of variance in this respect, such is expected to be in accordance with logical principles such as convenience, harmonisation, etc. It can thus be contended that the tonal misrepresentations discussed in this article could be said to be matters of orthographical convenience. By this it is assumed that the facts are apparent, but the most convenient approach to orthography design was adopted. However, if the tonal misrepresentations in question are merely matters of convenience, then all the analytical facts should still be spelt out such that anybody interested in the details can access them. In the cases discussed in this article, only a small fragment of these facts is available. Incidentally, the available facts do not even translate to the orthography.

This article proceeds by first introducing the reader to the three languages under study (Ebira, Gwari, and Igala), especially their sound systems in section 2. In section three, I present data on misrepresentation of downstep (DS). Here, attempts are made at explaining why the cases of misrepresentation arose. I go on in section four to discuss the implications of the identified DS misrepresentations, before considering and discarding an alternative approach to the analysis of our data. I consider the orthographical implication of DS misrepresentation in section five and the article is concluded in section six.

\section{Background to the Study}

The aspects of the sound and tone systems of the three languages under study that are relevant to this study are reviewed in this section. These include the consonant and vowel phonemes and the orthographic representation of each of them in the languages. The levels of tonemes and their variants as well as the nature of the DS in each language are also outlined.

\footnotetext{
1 The usual thing is to leave $\mathrm{M}$ unmarked in the orthographies of the three languages under study, for the sake of convenience.
} 


\subsection{Ebira}

Ebira is a West Benue-Congo language spoken by about 1'000'000 people in North-Central Nigeria. Ebira has nineteen consonant phonemes and nine vowels. The vowels form two sets in accordance with the operation of ATR vowel harmony in the language; /a/ agreeing with both sets (cf. Ladefoged 1964: 27; Adive 1989) (Tables 1-3). The consonant phonemes along with their orthographic representations are:

\begin{tabular}{|l|l|l|l|l|l|}
\hline S/n & $\begin{array}{l}\text { Phonemic } \\
\text { symbol }\end{array}$ & $\begin{array}{l}\text { Orthographic } \\
\text { symbol }\end{array}$ & S/n & $\begin{array}{l}\text { Phonemic } \\
\text { symbol }\end{array}$ & $\begin{array}{l}\text { Orthographic } \\
\text { symbol }\end{array}$ \\
\hline 1 & m & m & 11 & v & v \\
\hline 2 & n & n & 12 & s & s \\
\hline 3 & n & ny & 13 & z & z \\
\hline 4 & n & ng & 14 & h & h \\
\hline 5 & p & p & 15 & t & c \\
\hline 6 & b & b & 16 & d3 & j \\
\hline 7 & t & t & 17 & r & r \\
\hline 8 & d & d & 18 & w & w \\
\hline 9 & k & k & 19 & j & y \\
\cline { 1 - 2 } 10 & g & g & \multicolumn{2}{|l}{} \\
\cline { 1 - 2 } & & &
\end{tabular}

Table 1: Ebira consonant phonemes and their orthographic symbols

\begin{tabular}{|l|l|l|}
\hline S/n & Phonemic symbol & Orthographic symbol \\
\hline 1 & i & i \\
\hline 2 & e & e \\
\hline 3 & o & o \\
\hline 4 & u & u \\
\hline 5 & a & a \\
\hline
\end{tabular}

Table 2a: Ebira +ATR vowels and their orthographic symbols 


\begin{tabular}{|l|l|l|}
\hline S/n & Phonemic symbol & Orthographic symbol \\
\hline 1 & I & ị \\
\hline 2 & $\varepsilon$ & ẹ \\
\hline 3 & 0 & ọ \\
\hline 4 & U & ụ \\
\hline
\end{tabular}

Table 2b: Ebira -ATR vowels and their orthographic symbols

Ebira operates three contrastive tone levels, High (H), Mid (M), and Low (L) (1a-c), as well as the phonetic rising and falling contour tones $(2 \mathrm{a}-\mathrm{b})$. The language also has the downdrift phenomenon by which L depresses the height of other tones following it (cf. Adeniyi, 2009). In ( $3 \mathrm{c}$ and $\mathrm{f}$ ), we see instances where non-initial $\mathrm{L}$ depresses the $\mathrm{M}$ and $\mathrm{H}$, whereas it is initial $\mathrm{L}$ that depresses $\mathrm{M}$ and $\mathrm{H}$ in $(3 \mathrm{~d}-\mathrm{e})$. But initial $\mathrm{L}$ does not depress another $\mathrm{L}$; as a result it is only in (3a-b) that we have cases of downdrift L triggered by non-initial Ls which are second in the sequences. This reality of the downdrifting of the L in Ebira was acoustically proven in Adeniyi (2015).

(1) a. hú 'to drink'

b. $h \bar{u}$ 'to uproot'

c. hì̀ 'to roast in open fire'

(2) a. ró 'to make a hole through a wall or a door'

b. $y \hat{\imath}$ 'to refuse'

(3) a. ìgègè 'nail'

b. ìrùvò 'buttocks'

c. Ìrẹ̀sụ 'head'

d. ọzzộkō 'old person'

e. ọ̀nẹe 'female'

f. àdàvó 'mud'

Ebira has the downstep phenomenon by which $\mathrm{M}$ and $\mathrm{H}$ are lowered by floating $\mathrm{L}(4 \mathrm{a}-\mathrm{c})$ (cf. Elugbe, 1983; Adive, 1989; Adeniyi, 2009, 2015). Further, the DS in Ebira is total in nature.DS is said to be total when a higher tone is lowered so much that it may be perceived as if it is another level below it. This means that both downstepped H (DSH) and downstepped M (DSM) are realised at around the same level below the M, a situation resulting in perceptual overlapping between $\mathrm{H}$ and $\mathrm{M}$ (cf. Elugbe 1983). As such, the final tones in the output of both (4a) and (4b) are perceived alike. Figures 1 and 2 are of $(4 a-b)$ two identical sequences, with one having DSH, the other DSM; they show that there is only a difference of $4 \mathrm{~Hz}$ between DSH and DSM, a difference that is insignificant because it is not large enough to be perceptible to the human ear. It is worth emphasising at this point that unlike many other languages, DSH in Ebira is not realised at a level above the M, rather it is consistently realised below it. 
(4)
a. rị $\quad$ ụ̀rá $\rightarrow$ rụu $^{\downarrow}$ rá
eat pig 'eat pig (pork)'
b. rị ìrā $\rightarrow$ rí $^{\star}$ rā
eat fire 'burn'
c. ōzí ìzé $\rightarrow \bar{o}^{2}{ }^{\downarrow}{ }^{\star}$ zé
child personal 'Ize's child' name

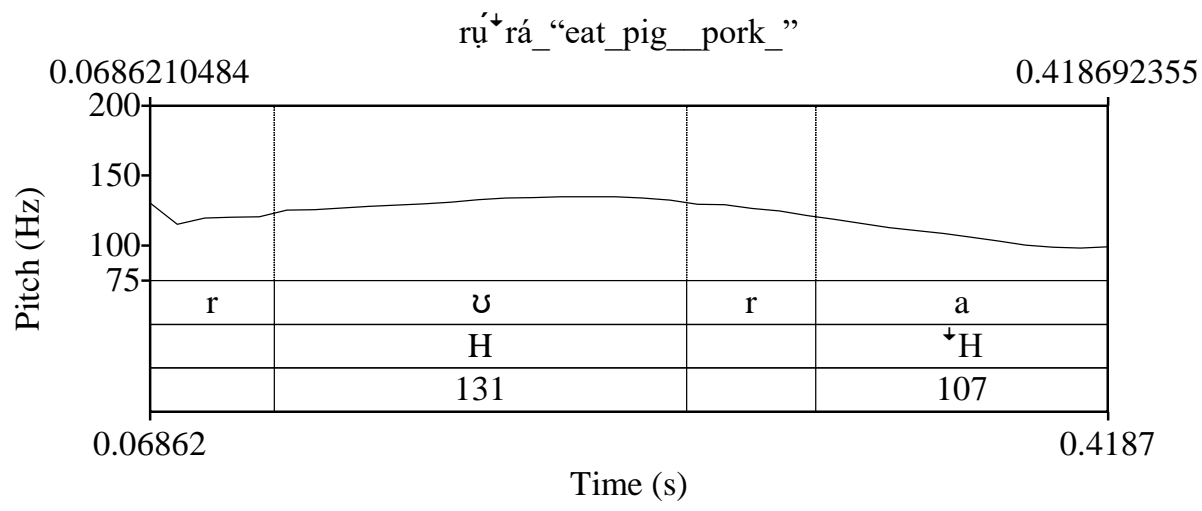

Figure 1: Pitch track of $r u^{\downarrow}{ }^{\dagger} a ́$ 'eat pig (pork)' showing the level of DSH

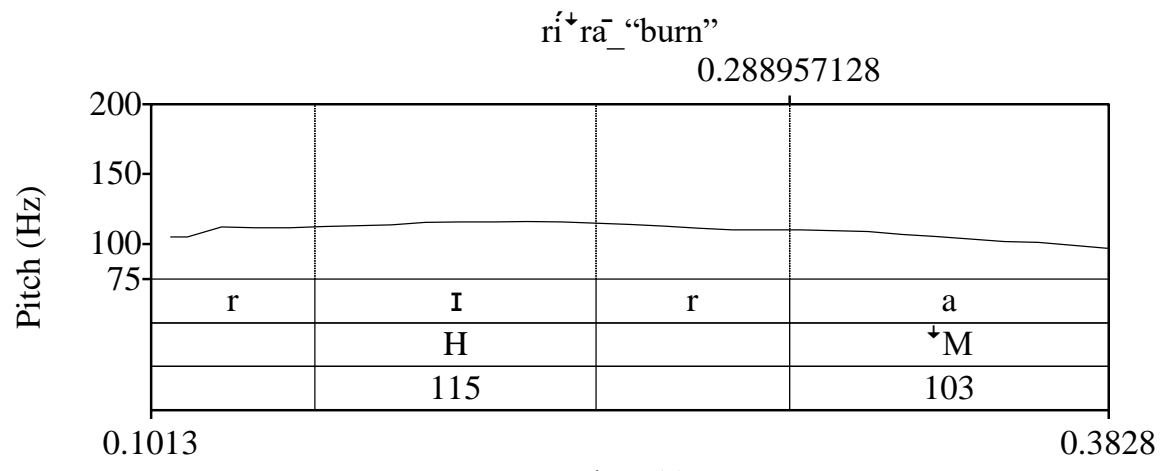

Time (s)

Figure 2: Pitch track of $r{ }^{i} r \bar{a}$ 'urn' showing the level of DSM

\subsection{Gwari}

Like Ebira, Gwari is a West Benue-Congo language spoken by about 700'000 speakers in North-Central Nigeria (cf. Gordon 2005). Gwari has 26 consonant phonemes, some of which are complex; and five vowels (Tables 3-4) (Hyman \& Magaji 1970). However, the Abuja variety of Gwari studied in this article has two additional phonemic vowel sounds: $/ \mathrm{o} /$ and $/ \varepsilon /^{2}$.

\footnotetext{
2 Hyman (1993) observed correctly that some dialects of Gwari have seven vowels.
} 


\begin{tabular}{|l|l|l|l|l|l|}
\hline S/n & $\begin{array}{l}\text { Phonemic } \\
\text { symbol }\end{array}$ & $\begin{array}{l}\text { Orthographic } \\
\text { symbol }\end{array}$ & S/n & $\begin{array}{l}\text { Phonemic } \\
\text { symbol }\end{array}$ & $\begin{array}{l}\text { Orthographic } \\
\text { symbol }\end{array}$ \\
\hline 1 & m & m & 14 & f & f \\
\hline 2 & n & n & 15 & v & v \\
\hline 3 & nj & ny & 16 & s & s \\
\hline 4 & nw & nw & 17 & z & z \\
\hline 5 & p & p & 18 & f & sh \\
\hline 6 & b & b & 19 & 3 & zh \\
\hline 7 & t & t & 20 & h & h \\
\hline 8 & d & d & 21 & t & ch \\
\hline 9 & k & k & 22 & d3 & j \\
\hline 10 & g & g & 23 & w & w \\
\hline 11 & kp & kp & 24 & wj & wy \\
\hline 12 & gb & gb & 25 & j & y \\
\hline 13 & 6 & 6 & 26 & 1 & l \\
\hline
\end{tabular}

Table 3: Ebira consonant phonemes and their orthographic symbols

\begin{tabular}{|l|l|l|}
\hline S/n & Phonemic symbol & Orthographic symbol \\
\hline 1 & i & i \\
\hline 2 & e & e \\
\hline 3 & E & e \\
\hline 4 & a & a \\
\hline 5 & 0 & o \\
\hline 6 & o & o \\
\hline
\end{tabular}




\begin{tabular}{|l|l|l|}
\hline 7 & $\mathrm{u}$ & $\mathrm{u}$ \\
\hline
\end{tabular}

Table 4: Gwari vowel phonemes and their orthographic symbols

Gwari operates three tones, $\mathrm{H}, \mathrm{M}$, and $\mathrm{L}(5 \mathrm{a}-\mathrm{c})$. As seen in $(6 \mathrm{a}-\mathrm{d})$, two contour tones also exist in the language: the rising tone and the falling tone. A high tone is realised as a rising tone after L $(6 \mathrm{a}-\mathrm{b})$, while a falling tone is realised when L follows $\mathrm{M}(6 \mathrm{c})$ or $\mathrm{H}(6 \mathrm{~d}-\mathrm{e})$, where it falls from the level of the preceding $\mathrm{M}$ or $\mathrm{H}$.

(5) a. mwá 'to beg'

b. gwō 'to grind'

c. gwò 'to receive'

(6) a. àchí $\rightarrow$ àchǐ 'needle'

b. gyìwyé $\rightarrow$ gyìwyě 'money'

c. ōzà $\rightarrow$ ōzâ 'person' (mid-falling)

d. sháknù $\rightarrow$ sháknû 'pot' (high-falling)

e. tnútnù $\rightarrow$ tnútnû 'work' (high-falling)

Gwari also has downdrift by which a mid tone is lowered by a preceding low tone (cf. Hyman \& Magaji 1970). A high tone is also subject to downdrift, but the L that triggers the lowering also spreads to the $H$, which blurs the lowering effect (cf. Adeniyi 2015). When the low tone triggering the downdrifting of the following non-low gets deleted in the flow of speech, as shown in example (7a-d), a DS results (cf. Adeniyi 2015).In (7a, c-d), we have a case of vowel elision triggering the deletion of $\mathrm{L}$; the non- $\mathrm{L}$ tone following the deleted $\mathrm{L}$ is then downstepped. But in (7c) the initial H in sháknù first spreads to the following L resulting in H-HL. The $\widehat{\mathrm{HL}}$ contour is then simplified during which $\mathrm{L}$ is lost and the spreading $\mathrm{H}$ takes its place completely. It is the loss of the L that triggers the downstepping of the following $\mathrm{M}$, which is apparent both perceptually and acoustically.
a. gyī ọ̣bmyā $\rightarrow$ gyī bmyā
eat fish 'eat fish'
$\begin{array}{lllll}\text { b. òwọ̄ lá } & \text { sháknù } & \text { zhīn } \rightarrow \text { wọ̄lá sháknú }{ }^{\star} \text { zhīn } \\ \text { he has } & \text { pot } & \text { make } & \text { 'he has made a pot' }\end{array}$
c. mè yá àchí lō nápí $\rightarrow$ mè yá ${ }^{\downarrow}$ chí lō nápí
I want needle it village 'I want the needle in the village'
d. gjē ọ̀pyá gmānyí lwé gmá $\rightarrow$ gjē `pyá gmānyí lwé gmá
look moon darkness at 'look at the moon in the dark'




\subsection{Igala}

Igala is also a West Benue-Congo language spoken by about 2'000'000 natives in Central Nigeria. Although the Igala-speaking area is adjacent to Ebira, similarities between them are minimal. Rather, Igala is said to be more closely related to Yoruba spoken is South-Western Nigeria (cf. Akinkugbe 1978; Ilori/Oyebade 2012). According to Ejeba (2009), Igala has 28 consonant (Table 5) and seven vowel phonemes (Table 6).

\begin{tabular}{|c|c|c|c|c|c|}
\hline $\mathbf{S} / \mathbf{n}$ & $\begin{array}{l}\text { Phonemic } \\
\text { symbol }\end{array}$ & $\begin{array}{l}\text { Orthographic } \\
\text { symbol }\end{array}$ & $\mathbf{S} / \mathbf{n}$ & $\begin{array}{l}\text { Phonemic } \\
\text { symbol }\end{array}$ & $\begin{array}{l}\text { Orthographic } \\
\text { symbol }\end{array}$ \\
\hline 1 & $\mathrm{~m}$ & $\mathrm{~m}$ & 15 & $\mathrm{~g}$ & $\mathrm{~g}$ \\
\hline 2 & $\mathrm{~m}^{\mathrm{j}}$ & my & 16 & $\mathrm{~g}^{\mathrm{W}}$ & $\mathrm{gw}$ \\
\hline 3 & $\mathrm{n}$ & $\mathrm{n}$ & 17 & $\widehat{\mathrm{kp}}$ & $\mathrm{kp}$ \\
\hline 4 & $\mathrm{n}$ & ny & 18 & $\widehat{\mathrm{gb}}$ & $\mathrm{gb}$ \\
\hline 5 & $\eta$ & ng & 19 & $\mathrm{f}$ & $\mathrm{f}$ \\
\hline 6 & $\mathrm{y}^{\mathrm{w}}$ & nw & 20 & $\mathrm{f}^{\mathrm{j}}$ & fy \\
\hline 7 & $\mathrm{p}$ & py & 21 & $\mathrm{~h}$ & $\mathrm{~h}$ \\
\hline 8 & $\mathrm{p}^{\mathrm{j}}$ & py & 22 & $\mathrm{t} \int$ & $\mathrm{ch}$ \\
\hline 9 & b & b & 23 & d3 & $\mathrm{j}$ \\
\hline 10 & $b^{j}$ & by & 24 & $\mathrm{r}$ & $\mathrm{r}$ \\
\hline 11 & $\mathrm{t}$ & $\mathrm{t}$ & 25 & W & W \\
\hline 12 & $\mathrm{~d}$ & $\mathrm{~d}$ & 26 & 1 & 1 \\
\hline 13 & $\mathrm{k}$ & $\mathrm{k}$ & 27 & $1^{\mathrm{j}}$ & ly \\
\hline 14 & $\mathrm{k}^{\mathrm{w}}$ & $\mathrm{kw}$ & 28 & $\mathrm{j}$ & $\mathrm{y}$ \\
\hline
\end{tabular}

Table 5: Igala consonant phonemes and their orthographic symbols (Adapted from Ejeba 2009: 13-15)

\begin{tabular}{|l|l|l|}
\hline S/n & Phonemic symbol & Orthographic symbol \\
\hline 1 & i & i \\
\hline 2 & e & e \\
\hline 3 & E & ẹ \\
\hline 4 & a & a \\
\hline 5 & 0 & ọ \\
\hline
\end{tabular}




\begin{tabular}{|l|l|l|}
\hline 6 & $\mathrm{o}$ & $\mathrm{o}$ \\
\hline 7 & $\mathrm{u}$ & $\mathrm{u}$ \\
\hline
\end{tabular}

Table 6: Igala vowel phonemes and their orthographic symbols (Adapted from Ejeba 2009: 8) Igala contrasts three tone heights, $\mathrm{H}, \mathrm{M}$, and L ( $8 \mathrm{a}-\mathrm{c})$.

(8) a. ré 'close'

b. rē 'pick'

c. rè 'make a drum'

Contour tones in Igala are formed in a way similar to Gwari; L is falling after $\mathrm{H}(9 \mathrm{a}-\mathrm{b})$, while $\mathrm{H}$ is rising after L (9c) (cf. Akinkugbe 1978).

(9) a. áchíkù $\rightarrow$ áchíkû 'bone'

b. ógwù $\rightarrow$ ógwû 'medicine'

c. èmí $\rightarrow$ èmǐ 'here'

In addition, Igala has the downstep phenomenon (cf. Ejeba 2009), which affects all the three tones of the language (cf. Adeniyi 2015). As shown in (10a-e) DS in Igala is triggered by both initial and non-initial floating L. But DSH is also triggered by initial and non-initial floating M (10f-g) (cf. Adeniyi 2015). Most of the previous authors on Igala do not recognise DSL. For instance, Ejeba (2009) recognised only DSH. Demonstrating DSL in Igala is however straightforward. Figure 3 below contains the pitch track corresponding to (10e); notice that the inputs to the utterance contain seven L tones, but there are only six in the output. The underlying $L$ that is missing in the output can straightforwardly be said to be that on the /a/ of the input word là "buy" which simply got deleted along with its host TBU. It is then not a coincidence that the tone immediately following this lost $\mathrm{L}$ is $10 \mathrm{~Hz}$ lower than the one preceding it (Fig.3). Observe further that L tones following this DSL are constrained under the ceiling set by the DSL, which is clear proof that the fourth tone is really DSL.

Also in Fig. 4, which is a representation of $(10 \mathrm{~g})$, we see the concatenation of $\mathrm{M}$ and $\mathrm{H}$ resulting in DSH. The proof that this is DSH and not $\mathrm{M}$ is simply the fact that at $138 \mathrm{~Hz}$, the $\mathrm{H}$ following it is significantly constrained when viewed in the light of the word-initial $\mathrm{H}$ realised at $151 \mathrm{H}$. In fact, this constrained $\mathrm{H}$ is lower than $\mathrm{M}$ preceding the DS realised at $141 \mathrm{~Hz}$. Likewise, one should ask why the downstepped tone is $11 \mathrm{~Hz}$ lower than a preceding $\mathrm{M}$ if it were to be regarded as $\mathrm{M}$. One does not expect that wide a margin between adjacent similar tones in a three-tone system. These arguments (also illustrated in $10 \mathrm{~b}$ and $\mathrm{f}$ ) are consistent with spoken Igala, and are all proof that in the concatenation of $\mathrm{MH}$ and $\mathrm{LH}$ across word boundaries resulting in the loss of one of the TBUs and one of the tones in Igala, the surviving tone is DSH and not M as popularly believed. Also, LM (10c) and LL (10e) concatenations in the same context yield DSM and DSL respectively. The presence of downstepping in these contexts may fly under the radar of the native speakers' perception because it really does not affect meaning; it only contributes to the state of being competent. 


\begin{tabular}{|c|c|c|c|c|c|}
\hline (10) & rú & èmí & & $\rightarrow$ & rwé ${ }^{\downarrow}$ mí \\
\hline & live & here & & & 'live here' \\
\hline b. & · lọ́ & àkọ́ & & $\rightarrow$ & lá kọ́ \\
\hline & bite & bead & & & 'bite the bead' \\
\hline c. & - tīdó & ùbì & ōchù & $\rightarrow$ & tīdó ${ }^{\star}$ byōchù \\
\hline & dance & behind & month & & 'dance after this month' \\
\hline d. & . ọ̀yákā & àkpẹ̀tẹ & & $\rightarrow$ & ọyákā kpẹ̀tẹ \\
\hline & story & stool & & & 'story about stool' \\
\hline e. & . òdùdẹ & là & ọgẹdẹ̀ & $\rightarrow$ & òdùdẹ̀ †lọ̀gẹ̀dẹ̀ \\
\hline & bat & buy & banana & & 'the bat bought banana' \\
\hline f. & $\operatorname{che}$ & ágbà & & $\rightarrow$ & ${ }^{\star}$ chágbà \\
\hline & make & basket & & & 'make a basket' \\
\hline g. & · ángẹjẹ̣ & kpā & ónú & $\rightarrow$ & ángẹjẹ̄ ^kpónú \\
\hline & tortoise & kill & thief & & "the tortoise killed thief" \\
\hline
\end{tabular}

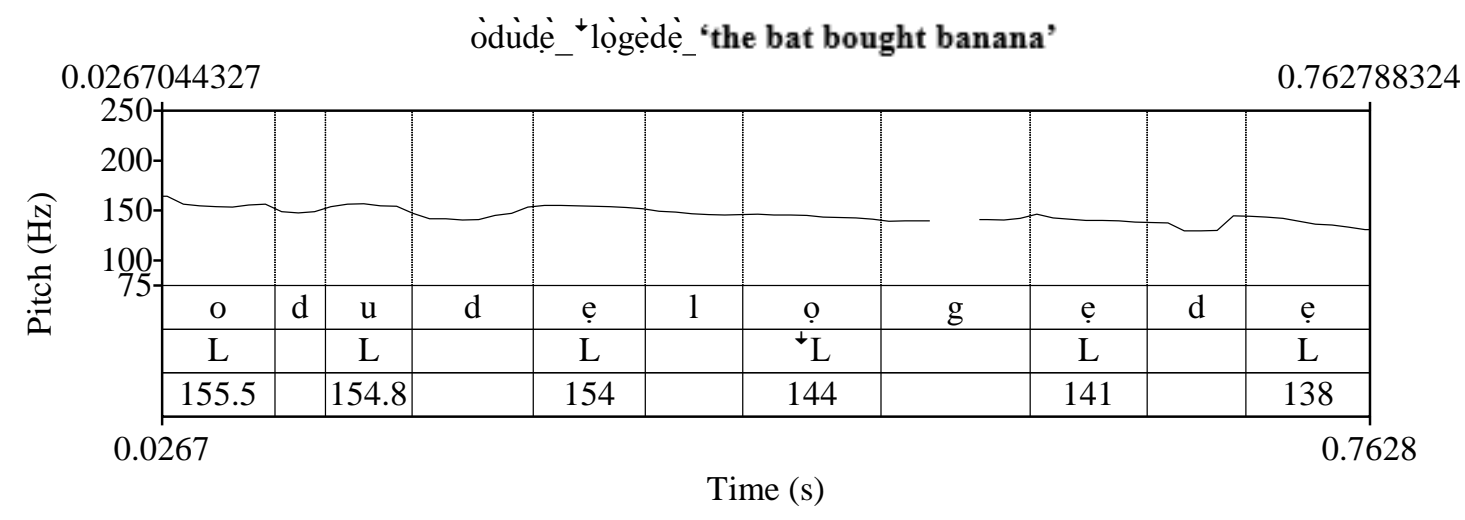

Figure 3: Pitch track of òdùdẹ lọgẹdẹ 'the bat bought banana' showing DSL and terracing 


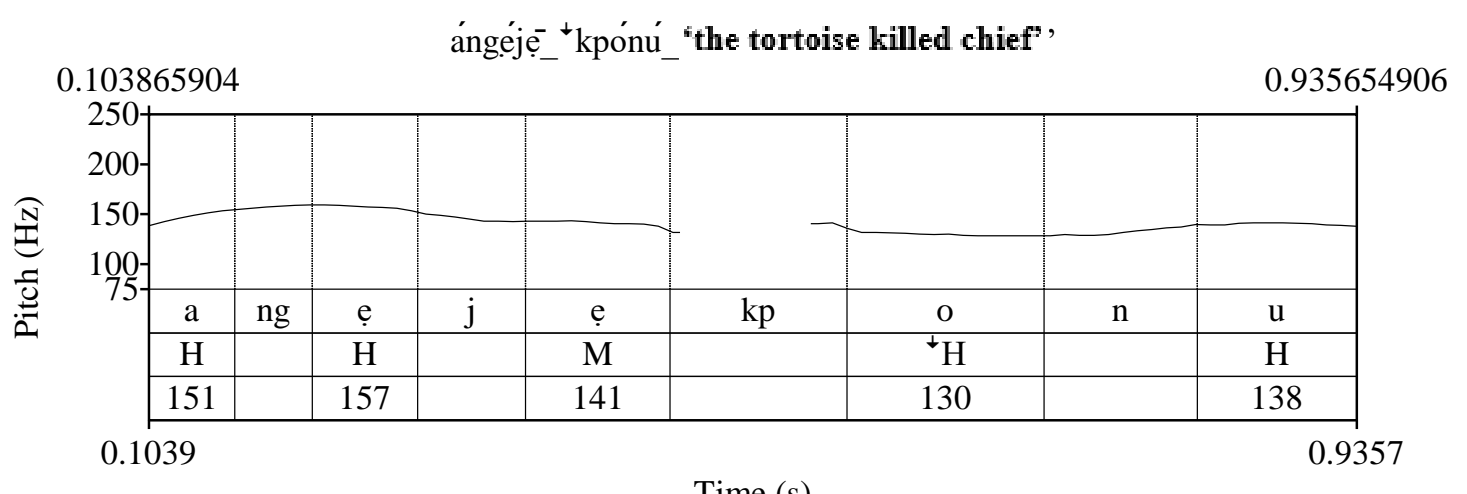

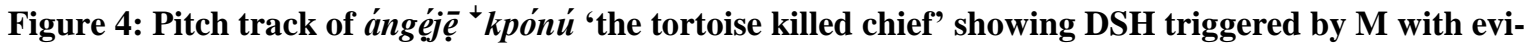
dence of terracing

\section{Orthographical Misrepresentation of Tones}

DS in Ebira, Gwari, and Igala is often misrepresented in the orthography. This misrepresentation usually takes the form of using the symbol of an entirely different tone in place of a downstepped tone. Initial data on these misrepresentations were gathered from published works on the languages (cf. Adive 1989; Hyman \& Magaji 1970; Tokula 2008; Ejeba 2009). Following this, literate speakers (trained linguists in the case of Ebira and Igala) were presented with data sets containing DS, but with tone completely unmarked. The speakers were then requested to tone-mark the data orthographically ${ }^{3}$.Instances of non-representation and misrepresentation of DS were then extracted as additional data for this article. A few examples of the misrepresentation are outlined in (11-15). Note that the current representation of DS in the orthographies of the languages is asterisked for reason of representational error; what should be the accurate representation is placed in parenthesis in each example, although a language can choose an exclamation mark or any other viable alternative in place of the superscript down arrow to represent DS. For each example, the inputs to the derivations are supplied to the left of the arrow, not necessarily because they are there from the sources; they are there to allow the reader appreciate the details of the DS misrepresentation.

It should be emphasised at this point that the fact that misrepresentation data were taken from some published works does not imply that those works did not recognise or mark DS at all. For instance, Adive (1989) recognised DS in Ebira, but he also says that DSH is perceptually the same as M, which implies a justification of the misuse of M in place of DSH by some other writers. But I prove otherwise in this work. Also in Gwari, Hyman and Magaji (1970) recognise DSM but regarded it merely as lowered M. Whereas a rising contour is said to be simplified to $\mathrm{M}$ in Hyman and Magaji, Adeniyi (2015) argued that it is really simplified to a DSH. In Igala, while previous works clearly recognise DS especially DSH (cf. Tokula 2008; Ejeba 2009 and the references therein), DSM and DSL are not recognised, except in (Adeniyi 2015 ; 2016). The summary is that extracting some data from published works does not imply

\footnotetext{
${ }^{3}$ In the case of Ebira and Igala, the first reaction from the speakers was that tone is rarely marked in the orthographies of their languages.
} 
that the authors of the works do not recognise DS at all; it is only that there is more to DS than is represented in those works.

\subsection{DS Misrepresentation in Ebira}

It is apparent from examples $(11 \mathrm{a}-\mathrm{c} ; 12 \mathrm{a})$ that DSH is often written as L for the reason of the totality of DS already mentioned. In (11g) where it is written as M, notice that the following $\mathrm{M}$ is then misrepresented as L. This is an apparent corollary of the terracing effect of DS in the language. DSM is also written as L in Ebira (11d-f).

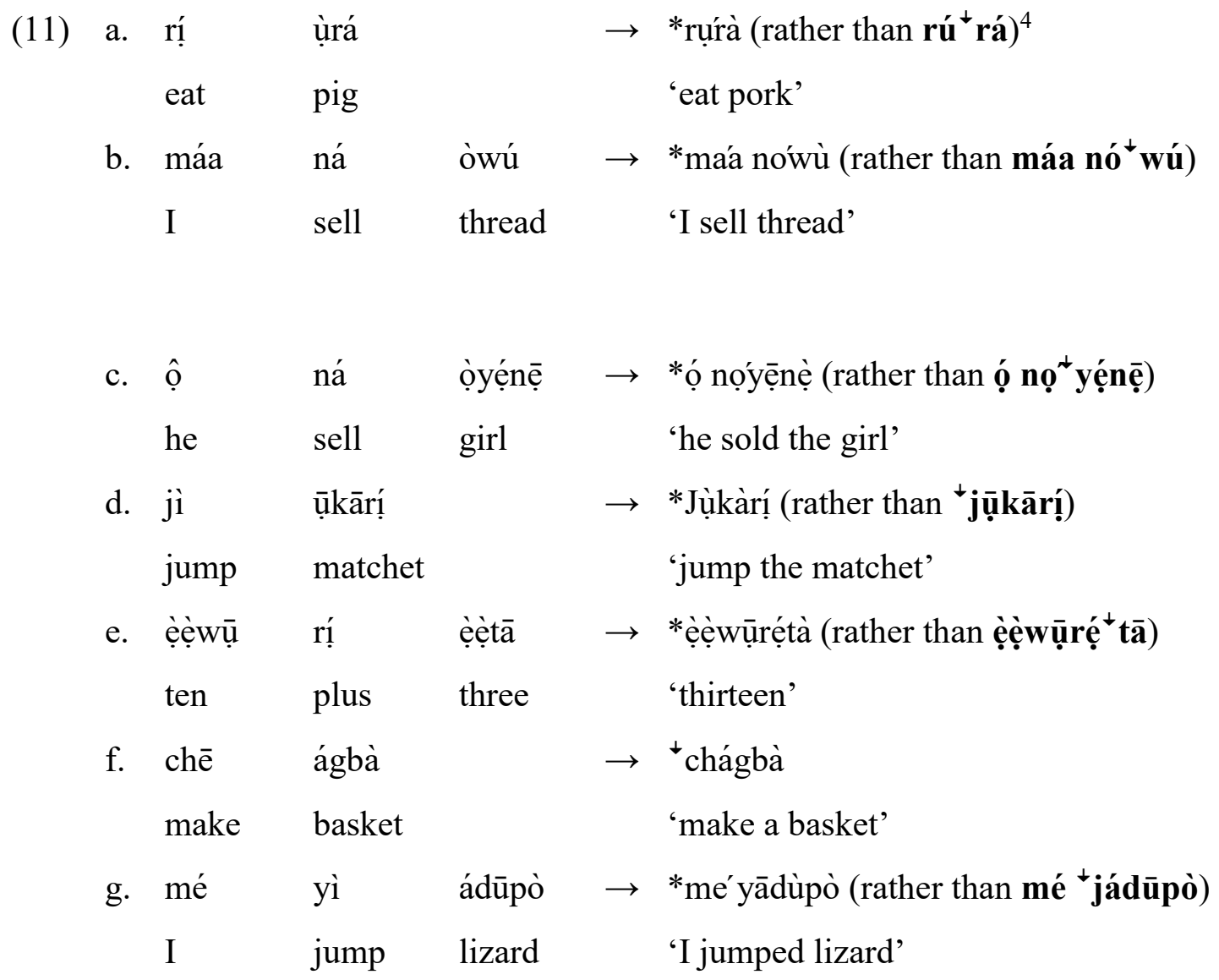

Examples $(12 \mathrm{a}-\mathrm{c})$ are genitive constructions where association between the nouns in each case is marked by a floating $\mathrm{H}$ tonal morpheme. The docking of this floating associative marker (AM) is best illustrated by (12c) where the input words contain no linked H. AM docks rightward and is thus realised on the prefix vowel of the word to its right (V2). This leads to the delinking of the L underlyingly on V2 which then triggers the downstepping of the utterance-final M. But notice that this DSM is written as L in the orthography.
a. ọ̀tá H àdá
$\rightarrow$ *ọ̀tádà (rather than ọ̀tá ${ }^{\downarrow}$ dá)
friend AM father
'father's friend'
b. ọ̀nyí $\quad \mathrm{H} \quad$ ọzọ̄gà
$\rightarrow \quad$ *ònyózògà (rather than ònyo» zōgà)

\footnotetext{
${ }^{4}$ Adive (1989: 63) rightly represents this as $\mathrm{H}^{\downarrow} \mathrm{H}$; but then goes on to say that DSH is the same as M. Thus, it is understandable if the practice among writers is not consistent with his DS analysis, but rather follows the perceptual impression.
} 


\begin{tabular}{|c|c|c|c|c|}
\hline mother & $\mathrm{AM}$ & stranger & & 'stranger's mother' \\
\hline ẹpẹ & $\mathrm{H}$ & àkụ & $\rightarrow$ & *ẹ̀pakụ̀ (rather than $\left.\grave{e ̣}^{\downarrow} \mathbf{p a ́}{ }^{\downarrow} \mathbf{k} \overline{\mathbf{u}}\right)$ \\
\hline soup & $\mathrm{AM}$ & guinea corn & & 'guinea corn soup' \\
\hline
\end{tabular}

The reason for misrepresenting DS in Ebira is clearly linked to the total nature of DS in the language in which both DSH and DSM are realised at a level below the M (cf. Elugbe 1983; Adeniyi 2009). In fact Adive (1989: 64) state specifically that " $\mathrm{H}^{\downarrow} \mathrm{H}$ is the same phonetically as HM," which, though slightly different from Elugbe (1983) and Adeniyi (2009), confirms the confusion of DS with some other basic tones in Ebira. Following extensive experimental investigations, Adeniyi $(2009,2015)$ report that the margin between M and L is acoustically small, and due to this factor, any tone below M (in this case DSM and DSH) is perceived closer to L. "After voiced consonants, $\mathrm{M}$ is realised at an average of $113.3 \mathrm{~Hz}$ while $\mathrm{L}$ is at 107.7 Hz. That leaves a margin of only about $5.6 \mathrm{~Hz}$ between the two tone levels, thus the tendency to perceive anything below the M as L" (Adeniyi 2015: 76). This is apparently the reason both types of DS are outrightly written as L in the orthography. DSH is sometimes written as $\mathrm{M}$ (and not necessarily L) but this is far less common.

\subsection{DS Misrepresentation in Gwari}

The misrepresentation of DS in Gwari is most noticeable in two ways; the downstepping of docked genitive H-tomorph often erroneously written as $\mathrm{M}$, and the simplification of $\widehat{\mathrm{LH}}$ rising contours also often written as M rather than DSH. Data in (13-14) below are taken from Hyman \& Magaji (1970), while the argument for the interpretation as DS issues were earlier advanced in Adeniyi (2015). Here, a highlight of the argument will do; genitive relation in Gwari is marked with a floating high tonal morpheme (tomorph) which obligatorily docks to the tone-bearing unit on its right. If the original tone on its eventual host is a non-high tone, then it displaces it. The docking of the H-tomorph is however guided by information on vowel elision in the sense that it does not dock on any noun prefix that is a candidate of elision; rather it jumps over such prefix and docks directly onto the stem (cf. Adeniyi 2015). When the prefix then gets elided, the now-docked associative marker becomes downstepped, and this is evident in the terracing effect it leaves on the subsequent tones within its tone group. This explains why the tone on ${ }^{\downarrow}$ bmyá in the output of example (13a) and that on ${ }^{\downarrow} p a ́$ in (13b) is DSH and neither of $M$ and $L$ respectively.

(13) Misrepresentation of DS in genitive constructions in Gwari
a. ẹ̣bí $\quad \mathrm{H} \quad$ ộbmyā $\quad \rightarrow \quad * e ̣ ̂ b i ́ 6 m y a ̄$ (rather than ẹ̣́í ${ }^{\downarrow}$ bmyá) child AM fish 'the child's fish'

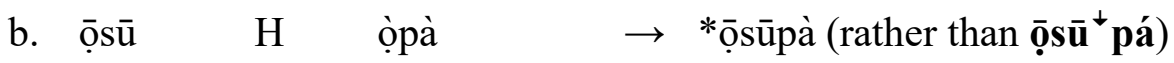
chief AM skin 'the chief's skin'

How the simplification of a falling contour tone results in DS was shown in (7b). In addition, the simplification of the $\widehat{\mathrm{LH}}$ rising contour tone also results in DS in Gwari. In such cases, it is observed that the $\mathrm{L}$ that originally spreads to a following $\mathrm{H}$ to form the contour in the first place often gets deleted. When this happens, the $\mathrm{H}$ becomes lowered, which is accurately 
termed DS, but often written as M. The rising contour in (14a) diachronically resulted from the spreading of a preceding L; notice that when this $\widehat{\mathrm{LH}}$ is now followed by gnikkwó 'market' the rise gives way for a level tone. But since the rising tone in this environment never did get to the usual height of H (cf. Hyman \& Magaji 1970; Adeniyi 2015), we can safely conclude that the resulting tone is DSH. The clear proof of this is the fact that the $\mathrm{M}$ and $\mathrm{H}$ following it are realised on levels lower than those preceding it. But the DSH is written as M in the orthography.

(14) Misrepresentation of DS in $\widehat{\mathrm{LH}}$ contour simplification in Gwari (cf. Hyman \& Magaji 1970: 17)

a. wọ̄ kú bě 'he/she has come’ $\rightarrow$ *wọ̄kú bē gnīkwó (rather than wộ kú `bé gnīkwó) 'he/she has come to the market'

b. gyìwyě 'money’ $\rightarrow$ *gyìwyē dā (rather than gyì wyé dā) 'possessor of money’

\subsection{DS Misrepresentation in Igala}

Examples (15a-g) show that DSH is misrepresented as M in Igala. This is easily illustrated by examples $(15 \mathrm{a}-\mathrm{b}, \mathrm{d}-\mathrm{e}, \mathrm{g})$ which contain no input $\mathrm{M}$; notice that the $\mathrm{M}$ surfacing in the outputs of these utterances take the place of input Hs. However, since these underlying Hs whose places are taken by the so-called $\mathrm{M}$ were preceded by $\mathrm{L}$ in the input, and the Ls are not realised in the output, it becomes clear that what we are dealing with are instances of DSH.

(15) Misrepresentation of DS in Igala ${ }^{5}$
a. ógwú ègwá twenty ten
b. ègwá ẹlá ten nine
$\rightarrow \quad{ }^{*}$ ógwẹ́gwā (rather than ógwệ ${ }^{\ddagger}$ gwá) 'thirty'
c. ójí hì ệlā
thief cook meat
$\rightarrow$ *ẹ̀gwẹ́lā (rather than ẹgwẹe lá) 'nineteen'
d. gwẹ̀ úkpò wash cloth
$\rightarrow \quad *$ gūkpò (rather than ${ }^{\downarrow}$ gúkpò) 'wash cloth'
$\rightarrow \quad$ *ójí hyệlā (rather than ójí ${ }^{\downarrow}$ hyệlā) 'the thief cooked meat'
e. ùkwù íngọ́ scent honey
f. ùchà ádẹ pot brass
$\rightarrow$ *ùkwīngọ́ (rather than ùkwíngọ́) 'scent of honey'
$\rightarrow$ *ùchādẹ̄ (rather than ù ${ }^{\downarrow}$ chádệ) 'pot of brass'
g. ùchà ámá kẹ́kẹe
$\rightarrow$ *ùchāmá kệkẹe (rather than ùch ${ }^{\downarrow}$ ámá kẹekẹe) pot clay small 'a small clay pot'

\footnotetext{
${ }^{5}$ Examples (15a-b) are taken from Armstrong (1965).
} 


\section{Discussion}

By far the most notable reason for the misrepresentation of DS in these languages is the stereotype initially held by linguists that DS is a preserve of two-tone systems and that it is incompatible with three-tone systems (cf. Elugbe 1985; Adeniyi 2015). By this, three-tone languages were erroneously described as operating discrete level tone systems, and were so treated to the extent that their tonal orthographies resulted basically from this. This means that the downstep phenomenon flew under the radar during phonological analyses and orthographical development of the languages. This was the reason rather than relate to the inputs to the utterances in (11-15) above, orthography designers simply related to their perception, which resulted in misrepresentation of the tones as well as a total disregard for what could have been a major contribution of DS to tonal orthographies.

From the point of view of perception, one can also identify the need to maximise perceptual distinctiveness as a key reason DS is not accorded a place in the orthographies of these languages. Phonological contrasts are usually well-adapted for communication (cf. Flemming, 2005). In order to achieve this, contrasts among sounds are required to be maximally distinct, which in effect eliminates confusion engendering tendencies (cf. Flemming, 2005). In essence, the perceptibility of a sound is not considered in isolation; it is considered in the light of other sounds that are perceptually close to it (cf. Wright, 2001; Martin \&Peperkamp, 2011).Thus, the downstepped form of a tone will be viewed alongside the tone level closest to it (L for DSM and DSH in Ebira, and M for DSH in Gwari and Igala). To take Ebira as a case study, the downstepped tones in (12) above are usually perceived as low tone. But taking cues from the words that serve as inputs to the utterances, it is clear that they are all lowered high and mid tones whose tones have been so reduced in height as to be perceived like a low tone. But if the tone in that position is said to be a low tone, then there will be a disconnect between the outputs of the constructions and their inputs: we will be saying that "the tone on a word in citation changes when it is used in context". But this is arbitrary and it is more natural to show via downstep that the tone does not just change to low; it is downstepped to that level due to the fact that the context supports the process. However, since contrasting DS with L is not distinct enough, listeners simply "merge" ${ }^{\prime}$ it with the L, and it is this merger that consequently undermines the recognition of the downstep phenomenon in the language. The same can be said of DSH versus M in Gwari and Igala.

These perception-motivated misrepresentations of DS constitute one key element in support of the view that "synchronic variability or diachronic change in sound patterns may be due to listeners' misperception" (cf. Hume \& Johnson, 2001). This is because representing DS as a tone distinct from it ( $\mathrm{L}$ in Ebira; $\mathrm{M}$ in Gwari and Igala) is a case of neutralisation (cf. Martin \& Peperkamp, 2011), which is synchronic, but if it is allowed to continue uncorrected, it will diffuse into the speech of future generations of speakers of the languages such that the legacies of the contrast will fade by and by. Indeed, this might actually be happening and manifesting in form of limitations against the consistency of DS in three-tone systems as against its totality in two-tone systems. In a terraced-level two-tone system, DS usually occurs without exemption whereas in three-tone systems, factors such as voicelessness of obstruents,

\footnotetext{
${ }^{6}$ By "merge" I mean the neutralisation of the contrast between low tone and downstep in Ebira.
} 
glide-formation, H-tone spreading, vowel height, complex syllable onsets, excitement, and formality of speech exert blocking effects on it (cf. Adeniyi, 2015).

An implication of the foregoing is that perception and communication are two key dictators of contrast-related phonological processes (cf. Hume \& Johnson, 2001). As a matter of fact, studies on perceptual cues in contrast maintenance in syllables show that while articulatory factors have their own roles, perception plays significant roles in ensuring that contrast is not lost (cf. Wright, 2001: 258-259).By this is meant that contrast is often enhanced, as against the merger between DS and basic tonemes observed in Ebira, Gwari, and Igala.

Hyman (2001) argues that there is a limit to how phonetics dictates to synchronic phonology. In some sense, arguments presented thus far point in a similar direction, since perception, which has birthed this problem is phonetic. The inference therefore is that perception plays significant roles in tonal phonology, but it has its limits. In the instance where it exceeds its limits, such problems as we have discussed in this article become inevitable.

One is then tempted to ask what exactly is the communicative load borne by DS. DS is not at the level of basic tonemes both in status and distribution; it is not another toneme, hence sacrificing it does not portend grave consequences on the phonology. However, sacrificing DS has its impact on communication as well as the impression of the speaker (Rialland 2001: 319, Adeniyi 2015: 206). This is because competence in these languages cannot be said to have been attained by any speaker who fails to accord DS its place in speech. This is not just the lowering of the downstepped tone but also the consequent terracing effect. This thus underlies the weight of the differences between phonology and phonetics; whereas phonology deals with sounds dissociated from the physical world (cf. Hume \& Johnson 2001), phonetics accommodates the physical world, including such things as the impression of the speakers, so to say. Both need to be captured in the phonological grammars of languages.

\section{$5 \quad$ DS and Tonal Orthographies}

The discussion and data provided in section 2 made it clear how the orthographies of some three-tone languages become inadequate by not marking tone adequately. Ejeba (oral communication) pointed out about Igala that tone is virtually not marked at all ${ }^{7}$, and when it is marked the practice is to represent DSH as $\mathrm{M}$, which misses the point. One fact of DSH in Igala as observed by Adeniyi (2015) and Ejeba (oral communication) is that it is only a little higher than M; essentially DSH is closer to $\mathrm{M}$ than it is to $\mathrm{H}$ in Igala. It is this that informed the perceptual error of writing it as $\mathrm{M}$.

The existing modes of writing the three languages studied in this article violate at least two basic principles or orthography: harmonisation and accuracy. For one, Ebira, Gwari, and Igala all belong to the West Branch of Benue-Congo and are all within the same region. In addition to Yoruba, Nupe, Ghotuo, and Yala (Ikom), they all operate three tone plus DS system (cf. Ejeba 2009; Adeniyi 2013, 2015). But in Ebira, DSH is sometimes written as L and some-

\footnotetext{
7 This problem is not limited to only three-tone systems; as at 1991, tone was not marked in Urhobo orthography. This, according to Elugbe (1991), had already become enshrined because the language already had an established written tradition.
}

ISSN 1615-3014 
times as $\mathrm{M}$, while it is outrightly written as $\mathrm{M}$ in Igala and Gwari. In the related languages of Yoruba and Nupe, DSH is written as $\mathrm{H}$ because its lowering effect is not wide enough to be confused with lower tones. This outlines the disparity in the writing of the same phenomenon in languages that are apparently related. ${ }^{8}$

Accuracy in orthography requires that the orthography must represent the sounds of the language. But the misrepresentation of DS in these three languages is a violation of this principle. It is imperative to note that a good orthography does not only represent faithfully, the significant sounds of the language, it also factors in the derivations/realisations of allophones via orthographic rules, pronunciation rules etc. This is why Seifart (2006: 277) defines an orthography as "a conjunction of a set of graphemes, such as an alphabet, and a set of accompanying rules regulating their use." In order to improve in this regard, there is the need to revisit the orthographies. By this is meant that DS needs to be recognised in all these three-tone systems of WBC and a unified way of representing it should be worked out.

A step in similar direction was proposed for the Assimilated Low Tone (ALT) in Yoruba by Bamgbose (1967). An ALT is a low tone that continues to exert effects on adjacent tones after it has been deleted itself. According to Bamgbose, ALT was "generally ignored" in grammars of the language, a state that should not be. He proposed a "dot" to be placed just at the position where the low tone has been deleted (Bamgbose 1967:6). Later works on Yoruba tone system have however argued that ALT is itself a form of DS (Adeniyi 2009). The point in all of these is that if ALT needs to be indicated in the orthography, so also is DS which has a more profound effect on the grammar of the language. Interestingly, ALT has also been found in Gwari and Ghotuo, two other three-tone systems of WBC, and for both languages, it has been argued to be a stage in the development of DS. Thus, if ALT deserves a place in orthographies of three-tone systems, DS should not be given less prominence.

\section{Conclusion}

It has been argued that DS is being misrepresented in the orthographies of Ebira, Gwari and Igala, and this is a logical consequence of misperception owing to the inability of speakers to identify a distinct contrast between it and the basic tonemes to which it is merged in each language. It is then contended that to avoid this mix-up, the DS phenomenon needs to be encoded in the phonological grammars as well as orthographies of these languages. One, the tone to which DS is merged is, many times, not the same as the downstepped tone, and not describing this in the grammar will leave a vacuum in terms of the tonal change (which is neutralisation). Another reason this needs to be included in the grammar is that the global terracing effect resulting from DS will also be unaccounted for once downstep itself is ignored.

This brings us to the question of how necessary it is to reflect DS in orthography. To the native speaker, it may be quite unnecessary because he/she acquired the language informally. But to the non-native who may be interested in learning the language, it is apparent that without also learning these details, his learning will always be fraught with deficiencies. There is yet another dimension to this question worthy of note. Supposing these languages are to be

\footnotetext{
${ }^{8}$ As a matter of fact, Igala is so close to Yoruba that many tend to see it as a dialect of Yoruba. And there have been a lot of research works comparing Igala with dialects of Yoruba (see Akinkugbe 1976 for instance).
} 
synthesised, the machine is prone to taking the erroneous $\mathrm{M}$ of Gwari and Igala as real $\mathrm{M}$, in which case it will ultimately miss the facts of terracing in the languages, even to the extent of categorising following H's as M's because they are subject to the ceiling effect. In the case of H's written as L in Ebira, the machine will also be prone to recognising it as a normal L, in which case the connection with the underlying tone will be lost. The loss of the connection between an underlying tone and an erroneous one taking its place in speech has a further implication for synthesis. It means the machine will have to learn them separately. In this case it will be said that in Ebira àdá and dà in 'father' and 'father's friend' are not from the same source, but must be seen as different entries for 'father' in different contexts, which will itself be in error since we know that it is vowel elision that takes off the prefix vowel and then DS lowers the tone on the stem, but the resultant tone is then erroneously written as a different one. By relating to DS, this sort of errors will automatically be avoided.

This article has highlighted problems that the orthographies of Ebira, Gwari, and Igala are fraught with while arguing for more phonemically accurate orthographies; but whether it will result in orthographical adjustments or not depends on several factors, one of which is how entrenched the current orthographies of the languages concerned are, and how willing the speakers of those languages are to effect and or accept change.

\section{References}

Adeniyi, Kolawole (2009): The typology of three-tone systems: Ebira, Ghotuo, Yala (Ikom), and Yoruba. M. A. Thesis, University of Ibadan.

Adeniyi, Kolawole (2013): "On the status of the downstep in Yoruba". In: Ndimele, OzoMekuri/Mustapha, Ahmad/Yakasai,Hafisu Miko (eds.):Language, Literature \& Culture in a Multilingual Society. A Festschrift for Abubakar Rasheed. Port Harcourt, M \& J Grand Orbit Communications \& Emhai Press: 787-802.

Adeniyi, Kolawole (2015): Downstep in three-tone systems of West Benue-Congo languages. Nigeria: University of Ibadan.

Adeniyi, Kolawole (2016): "Downstep in Igala and Yala (Ikom)". Journal of West African Languages 43/1: 1-21.

Adive, John (1989): The verbal Piece in Ebira. Dallas: SIL International Publications.

Akinkugbe, Femi (1978): A comparative phonology of Yoruba dialects, Isekiri and Igala. University of Ibadan, Nigeria.

Akinlabi, Akinbiyi (2004): "The sound system of Yoruba". In: Lawal, Nike/Sadiku, Matthew/Dopamu, Ade (eds.): Understanding life and culture: Yoruba. New Jersey, Africa World Press: 453-468

Armstrong, Robert (1965): "Comparative wordlist of two dialects of Yoruba with Igala". Journal of West African Languages 2/2: 51-78.

Bamgbose, Ayo (1965): Yoruba orthography. Ibadan: University Press

Bamgbose, Ayo (1967): A short Yoruba grammar. Ibadan: Heinemann.

Bamgboṣe, Ayo (1990): Fonólọjì àti girámà Yorùbá. Ibadan: University Press.

Ejeba, Salem Ochala (2009): A grammar of Igala tones. Unpublished M. A. Thesis, University of Port Harcourt. 
Elugbe, Ben (1983): Aspects of Ebira phonology. Seminar paper, Dept. of Linguistics and Nigerian Languages, University of lbadan.

Elugbe, Ben (1985): "The Tone System of Ghotuo". Cambridge Papers in Phonetics and Experimental Linguistics 4: 1-21.

Elugbe, Ben Ohi (1991): "The Limit of accuracy in the design of orthographies". Journal of West African Languages XXI/1: 49-54.

Flemming, Edward (2005): "Speech perception in phonology". In: Pisoni, David/Remez, Robert (eds.): The handbook of speech perception. Malden etc., Blackwell: 156-182.

Hume, Elizabeth \& Johnson, Keith (2001): “A model of the interplay of speech perception and phonology". In: Hume, Elizabeth/Johnson, Keith (eds.):The role of speech perception in phonology. New York, Academic Press: 3-26.

Hume, Elizabeth \& Johnson, Keith (eds.) (2001): The role of speech perception in phonology. New York: Academic Press.

Hyman, Larry (1970): “How Concrete is Phonology?”Language 46: 58-76.

Hyman, Larry (1993): "A phonological study of the Gwari lects. Review of H. J. Rosendall”. Phonology 10: 345-346.

Hyman, Larry (2001): "The limits of phonetic determinism in phonology". In: Hume, Elizabeth \&Johnson, Keith (eds.): The role of speech perception in phonology. New York, Academic Press: 141-186.

Hyman, Larry \& Magaji, Daniel (1970): Essentials of Gwari grammar. Ibadan: Institute of African Studies' Occasional Publication 27.

Ilori, Johnson Folorunso/Oyebade, Francis Olugbenga (2012): "Negation in Igala". Entrepalavras, Forbaleza-ano 2, 2/1: 25-40.

Ladefoged, Peter (1964): "Igbirra notes and wordlists". Journal of West African Languages 1/1: 27-37.

Lojenga, Constance Kutsch (2011): "Orthography and Tone: Tone system typology and its implications for orthography development". Paper presented at: Linguistic Society of America Annual Meeting, Pittsburg, Jan., 2011.

Martin, Andrew \& Peperkamp, Sharon (2011): "Speech perception and phonology". In: Oostendorp, Marcvan/Ewen, Colin/Hume, Elizabeth/Rice, Keren (eds.): The Blackwell Companion to Phonology. Oxford, Blackwell: 2334-2356.

Rialland, Annie (2001): “Anticipatory raising in downstep realisation: evidence for preplanning in tone production”. In: Kaji, Shigeki (ed.): Proceedings ofcross-linguistic studies of tonal phenomena. Tokyo, Institute for the Study of Languages and Cultures of Asia and Africa: $301-321$.

Seifart, Frank (2006): “Orthography development”. In: Gippert, Jost/Himmelmann, Nikolaus/Mosel, Ulrike (eds.): Essentials of language documentation. New York, Mouton de Gruyter: 275-299.

Tokula, Lillian Unekwu (2008): Reduplication in Igala: an Autosegmental analysis. Nigeria: University of Ibadan.

Williamson, Kay (1980): Reading and writing Ikwerre. Ibadan: Institute of African Studies.

Williamson, Kay (1984): Practical orthography in Nigeria. Ibadan: Heinemann Educational Books. 
Wright, Richard (2001): "Perceptual cues in contrast maintenance". In: Hume, Elizabeth/Johnson, Keith (eds.): The role of speech perception in phonology. New York, Academic Press: 251-278. 